\title{
Recurrent, thermally-induced shifts in species distribution range in the Humboldt current upwelling system
}

\author{
D. Carstensen ${ }^{\mathrm{a}, *}$, J.M. Riascos ${ }^{\mathrm{b}}$, O. Heilmayer ${ }^{\mathrm{c}}$, W.E. Arntz ${ }^{\mathrm{a}}$, J. Laudien ${ }^{\mathrm{a}}$ \\ ${ }^{a}$ Alfred Wegener Institute for Polar and Marine Research, Section Bentho-Pelagic Processes, P.O. Box 120161, D-27515 Bremerhaven, Germany \\ ${ }^{\mathrm{b}}$ Universidad de Antofagasta, Instituto de Investigaciones Oceanológicas, Avenida Universidad de Antofagasta 02800, Antofagasta, Chile \\ ${ }^{c}$ German Aerospace Center, Heinrich-Konen-Str. 1, D-53225 Bonn, Germany
}

\section{A R T I C L E I N F O}

Article history:

Received 18 January 2010

Received in revised form

9 June 2010

Accepted 14 June 2010

\section{Keywords:}

Beaches

Calcein marking

Clams

Donax obesulus

El Niño

Mesodesma donacium

Growth

Temperature stress

\begin{abstract}
A B S T R A C T
El Niño-Southern Oscillation (ENSO) is a global climate variablility, which fundamentally influences environmental patterns of the Humboldt Current System (HCS) off Chile and Peru. The surf clams Donax obesulus and Mesodesma donacium are dominant and highly productive bivalves of exposed sandy beaches of the HCS. Existing knowledge indicates that El Niño (EN, warm phase of ENSO) and La Niña (LN, cold phase of ENSO) affect populations of both species in a different way, although understanding of the mechanisms underlying these effects is still lacking. The aim of this study was to test hypotheses attempting to explain field observations on the effect of strong EN or LN events by using controlled experimental conditions. Growth and mortality rates of both species were registered during a four-week experiment under EN temperature conditions, normal temperature conditions and LN temperature conditions. While $D$. obesulus exhibited reduced growth and higher mortality under LN conditions, $M$. donacium showed reduced growth and higher mortality under EN conditions. The results clearly indicate different temperature tolerance windows for each species, possibly reflecting the evolutionary origins of the Donacidae and Mesodesmatidae in regions with contrasting temperature regimes. These results provide experimental support for previous hypotheses suggesting that thermal tolerance is the driving factor behind observed changes in the species distributions of $D$. obesulus and $M$. donacium during the extreme phases of ENSO.
\end{abstract}

(c) 2010 Elsevier Ltd. All rights reserved.

\section{Introduction}

The Humboldt Current System (HCS) is among the most productive marine ecosystems in the world. Strong, coastal upwelling driven by trade winds brings deep, nutrient-rich water into the euphotic layer, fueling vast primary production. Unlike other coastal ecosystems at similar latitudes, the HCS exhibits cool, stable temperature conditions throughout the year. According to Thiel et al. (2007, Fig. 1), three biogeographical units can be distinguished within the HCS: (i) the first northern unit dominated by subtropical and temperate biota and extending from northern Peru to northern Chile $\left(4-6^{\circ} \mathrm{S}\right.$ to $\left.30-36^{\circ} \mathrm{S}\right)$; (ii) the second southern unit dominated by a subantarctic and temperate biota extending from the Chilean archipelago to the Magellan Province $\left(41-43^{\circ} \mathrm{S}\right.$ to $\left.54^{\circ} \mathrm{S}\right)$; and (iii) in between, a transitional unit characterized by strong numerical reductions in subantarctic and subtropical species at its northern and southern borders

\footnotetext{
* Corresponding author. Tel.: +49 (0) 47148311315; fax: +49 (0) 47148311918.

E-mail address: Daniel.Carstensen@awi.de (D. Carstensen).
}

respectively $\left(30-36^{\circ} \mathrm{S}\right.$ to $\left.41-43^{\circ} \mathrm{S}\right)$. These biogeographical units are subject to continual fundamental changes caused by the $\mathrm{El}$ Niño-Southern Oscillation (ENSO), the strongest signal in the interannual variation of the ocean-atmosphere system (Wang et al., 1999). During El Niño (EN, the warm phase of ENSO) and La Niña (LN, the cold phase of ENSO) events, multiple and contrasting abiotic changes trigger strong biotic changes, including alternations in species composition, abundance and biomass (e.g. Tarazona et al., 1985; Arntz and Fahrbach 1991; Castilla and Camus, 1992; Riascos, 2006; Thatje et al., 2008). Taking into account the normally stable thermal regime of the HCS and the strong thermal anomalies associated to the extremes of ENSO, temperature has been proposed as a key factor driving changes at the population and community level, and thereby influencing community structure and the latitudinal distributions of marine benthic organisms within this system (e.g. Soto, 1985; Tomicic, 1985; Arntz and Fahrbach 1991; Díaz and Ortlieb, 1993; Urban, 1994; Laudien et al., 2007). Unfortunately, cause-and-effect explanations of the described changes during extremes of ENSO are hampered by the lack of experimental and physiological evidence (Arntz et al., 2006; Thatje et al., 2008). 


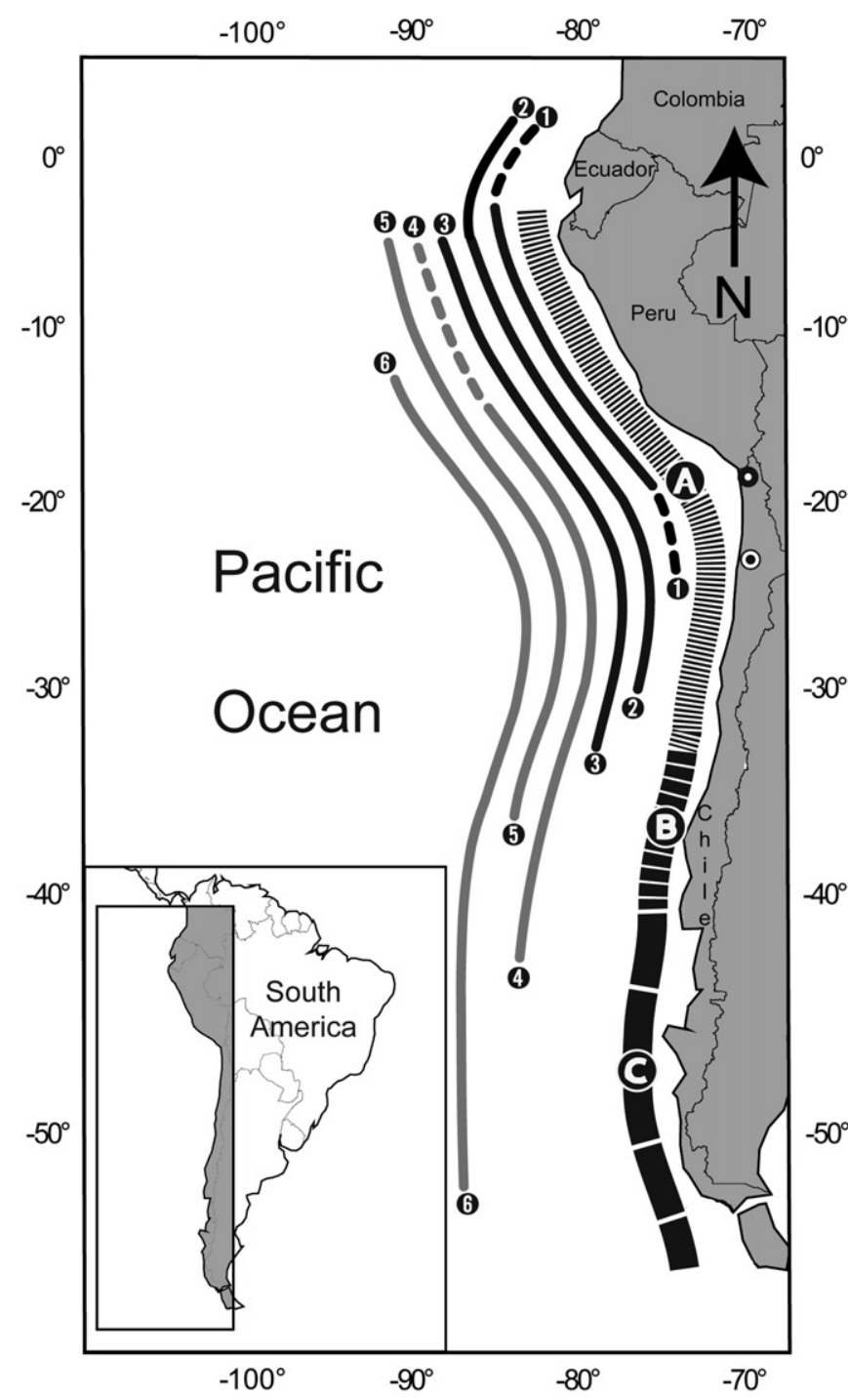

Fig. 1. Biogeographical units of the Humboldt Current System after Thiel et al. (2007): A: The Peruvian province, B: The transition zone and C: The Magellanic province. Sample location of Donax obesulus $\boldsymbol{0}$ in Arica; Chinchorro beach and Mesodesma donacium $\odot$ in Antofagasta; Hornitos beach. Lines in black indicate species with tropical origin: $\mathbf{0}$ Black and black dashed lines indicate historic distribution of D. obesulus after Coan (1983). Black line indicates current distribution after an ample sampling. 2 Distribution of Argopecten purpuratus and 3 Thais chocolata after Guzmán and Viana (1998a). Lines in grey indicate species with tropical origin: $\mathbf{4}$ Grey and grey dashed lines indicate historic distribution of $M$. donacium after Tarifeño (1980). Grey line indicates current distribution after an ample sampling. 6 Distribution of Semimytilus algosus after Olsson (1961). 6 Distribution of Aulacomya ater after Guzmán and Viana (1998a). For further details see Table 3.

Donax obesulus Reeve, 1854 and Mesodesma donacium Lamarck, 1818 are two common surf clams of reflective and dissipative sandy beaches. Whereas $D$. obesulus is restricted to the intertidal zone, $M$. donacium inhabits both, the intertidal (juveniles) and the shallow subtidal (adults) (Riascos et al., 2008). Both species show high abundance along their distribution range in the HCS (Carstensen, 2010; Arntz et al., 1987). These species occupy the same niche and have similar ecological roles (Tarazona et al., 1986; Beu, 2006). Therefore, strong competitive interactions may be expected, such as reported between Donax hanleyanus and Mesodesma mactroides at the Atlantic coast of South America (Defeo and de Alava 1995; Herrmann et al., 2009). As poikilothermic organisms, their temperature is directly dictated by the temperature of the surroundings. A small increase of the 'normal operating temperature range' of an organism can reduce scope for growth and reproduction (Pörtner et al., 2005, Pörtner and Knust, 2007; Wang and Overgaard, 2007).

Within their distributional range both species are affected differently by extreme phases of ENSO (Soto, 1985; Arntz et al., 1987, 1988, Arntz and Fahrbach, 1991; Díaz and Ortlieb, 1993; Thiel et al., 2007). Historically, D. obesulus (synonyms: D. marincovichi and D. peruvianus; Carstensen et al., 2009) was distributed from the Ecuadorian coast $\left(0^{\circ} 26^{\prime} \mathrm{S}\right)$ to the North of Chile $\left(23^{\circ} 05^{\prime} \mathrm{S}\right)$ (Coan, 1983; Fig. 1) and temporarily expands its distribution range southward during strong EN episodes (Tomicic, 1985). In contrast, the historic distribution of $M$. donacium spans from Chiloé, southern Chile $\left(16^{\circ} 36^{\prime} S\right)$ to Sechura, northern Peru $\left(42^{\circ} 23^{\prime} S\right)$ (Tarifeño, 1980; Fig. 1). During EN, the species suffers mass mortalities in the northern part of its geographical range (Tomicic, 1985; Arntz et al., 1987; Guzmán et al., 1998b).

Generally, the distributional ranges of species are determined by different and interacting contributory factors, including environmental conditions, species interactions and population demographics (Sagarin et al., 2006). Apart from purely descriptive accounts, some evidences suggest that distribution shifts may not be entirely explained by corresponding shifts in temperature. First, it is not clear whether sympatric $D$. obesulus and $M$. donacium develop competitive interactions (Arntz et al., 1987). Second, $M$. donacium reveals a remarkably poor ability to recover its former distribution following EN events in spite of several cycles of warm and cold (Arntz et al., 2006). Third, parasitic interactions and, interspecific interactions generally have been shown to play a role in mortality events and species distribution (Dugan et al., 2004; Riascos et al., 2008). In this context, determining the physiological responses of particular species to temperature would provide a mechanistic understanding of the observed changes and discriminate this factors from others contributing to changes in distribution.

Therefore, this study aimed to (i) evaluate experimentally the effect of temperatures typically observed during EN and LN events on growth and mortality of the two surf clams, and (ii) compare these results with the observed changes in distribution. Therefore, bivalves were collected from the current southernmost extent of the $D$. obesulus disributional range of, and from the northernmost point in the $M$. donacium disributional range, both within the area impacted by the cold and warm episodes of ENSO, and used in a series of in vitro-experiments.

\section{Material and methods}

\subsection{Distribution and sampling site}

Given that EN and LN have caused changes in the historical distributional range of both study species, an ample sampling and a compilation of historical data were performed to determine the current southern distribution limit of D. obesulus (Carstensen, 2010), and the current northern distribution limit of $M$. donacium along the Peruvian and Chilean coast (Riascos, 2008). The southernmost population of $D$. obesulus was located at Chinchorro beach (Northern Chile, Arica, $18^{\circ} 27^{\prime} 53.8^{\prime}$ S; $70^{\circ} 18^{\prime} 24.3^{\prime} \mathrm{W}$; Fig. 1). The northernmost population comprising the full range of size classes of $M$. donacium was found at Hornitos beach (Antofagasta, $22^{\circ} 54.99^{\prime} \mathrm{S}$; $70^{\circ} 17.42^{\prime} \mathrm{W}$; Fig. 1 ). Specimens of both species were collected in February 2007 (D. obesulus, $n=104$; M. donacium, $n=122$ ) and transported to the laboratory. To minimize stress, clams were transported within $12 \mathrm{~h}$ of collection and transferred immediately to laboratory conditions at the Marine Laboratory of the University of Antofagasta. 


\subsection{In vitro-experiment}

During the first two weeks after collecting, the bivalves were acclimatized in the laboratory at the temperatures corresponding to local conditions at the collection sites (D. obesulus: $17.8^{\circ} \mathrm{C}$; M. donacium: $17.4^{\circ} \mathrm{C}$ ). Low mortality ( $<5 \%$ ) was observed during the acclimatization period. The sampling sites for each species lies approximately $800 \mathrm{~km}$ apart, hence the slight difference in temperature. Considering this, experimental temperatures were set to mimic normal temperature conditions (NTC), El Niño typical temperature conditions (ENTC) and La Niña typical temperature conditions (LNTC) at each sampling site (Fig. 1). Temperatures were defined according to the analysis of a long-term (1980-2006) sea surface temperature (SST) data archived in the database of the Servicio Hidrográfico y Oceanográfico de la Armada de Chile (available from http://www.shoa.cl). For D. obesulus, NTC was defined as the long-term annual mean SST $\left(17.8^{\circ} \mathrm{C}\right)$, ENTC reflected the highest monthly mean SST registered during EN 1982-1983 $\left(24.6^{\circ} \mathrm{C}\right)$, and LNTC mimicked the lowest monthly mean SST during LN $1990\left(14.9^{\circ} \mathrm{C}\right)$ at the Arica station $\left(18^{\circ} 28^{\prime} \mathrm{S}, 70^{\circ} 19^{\prime}\right)$. Similarly, for M. donacium NTC was set to $17.4{ }^{\circ} \mathrm{C}$, ENTC was $24.2^{\circ} \mathrm{C}$, and LNTC was $14.5^{\circ} \mathrm{C}$.

After acclimatization, the shell length (maximal anterior-posterior shell length; SL) of each specimen was measured to the nearest $0.01 \mathrm{~mm}$ with a vernier caliper and the specimen was tagged with a consecutive code to ensure individual identification. Thereafter, clams were incubated for $3 \mathrm{~h}$ in moderately aerated, filtered seawater containing $50 \mathrm{mg} \mathrm{l}^{-1}$ Calcein (Sigma, CAS 146115-0) to incorporate a non-deleterious fluorescent mark in the shell, that would allow the measurement of short-term (i.e. daily) growth increments (Riascos et al., 2007). Thereafter, clams were randomly assigned to a single factor (temperature), three-level (NTC, ENTC, LNTC) experimental design, with three replicate aquaria per level and 12 individuals of $D$. obesulus and 16 individuals of $M$. donacium per replicate.

Specimens were maintained under experimental conditions in closed circulation systems for 31 days (March 2007) in a 12:12 h day-night cycle. Aquaria were filled with filtered $(1 \mu \mathrm{m})$ seawater and sufficient sand for clams to be able to retract completely ( $\sim 13 \mathrm{~cm}$ depth). Experimental temperature was maintained within a $0.3{ }^{\circ} \mathrm{C}$ fluctuation range, using a computer-controlled system. Sand was aerated and $\sim 15 \%$ of the water was replaced daily to minimize water pollution by accumulation of nutrients $\left(\mathrm{NH}_{4}^{+}, \mathrm{NO}_{2}^{-}\right.$, $\mathrm{NO}_{3}^{-}$) from excreted waste. Animals were fed daily with a mixture (50:50) of Isochrysis galbana (T-ISO) and Chaetoceros calcitrans $\left(\sim 40.000\right.$ cells $\left.\mathrm{ml}^{-1}\right)$ ad libitum. Dead animals (open shell, foot and siphons extended) were removed on a daily basis and shells were cleaned and stored for further analysis.

At the end of the experiment, all animals were sacrificed, soft parts were removed and shells oven-dried at $65{ }^{\circ} \mathrm{C}$ for $24 \mathrm{~h}$. A section through the right valve of each clam was obtained by cutting across the longest growth axis and the section embedded in epoxy-resin. In order to clearly identify the Calcein mark included in the shell, the surface of the resulting section was polished using a speed grinder-polisher (Buehler, Alpha, 2 Speed Grinder-Polisher) with grinding paper $(200 \mu \mathrm{m}-5 \mu \mathrm{m})$ and a polycrystalline diamond suspension $(1 \mu \mathrm{m}-0.05 \mu \mathrm{m})$. Microgrowth was measured (to the nearest $\mu \mathrm{m}$ ) from the Calcein mark to the shell edge, by analyzing digital fluorescence micrographs (blue light, $460-490 \mathrm{~nm})$. The daily growth rate $\left(\mu \mathrm{m} \mathrm{day}^{-1}\right)$ was calculated for each specimen. Mortality of each species was calculated from the daily percentage of surviving clams throughout the experimental period (31 days). A dosage-mortality approach (Urban, 1994) was used to determine the point at which $50 \%$ of the experimental population had died $\left(\mathrm{LT}_{50}\right)$. This parameter was obtained by plotting the relationship between time and mortality, and extrapolating the time corresponding to $50 \%$ mortality.

\subsection{Statistical analysis}

To evaluate the effect of temperature on growth rate $\left(\mu \mathrm{m} \mathrm{day}^{-1}\right)$, the general linear model (GLM) procedure in JMP 7.0.1 (SAS Institute Inc.) was used to apply a one-way analysis of covariance (ANCOVA) model. The model treated temperature as a fixed effect, growth rate as the response variable and shell length as the covariate under the full interaction (separate slopes) model approach. Therefore, the interactions between the covariate and the main effects were included as additional effects. In order to deal with variation within replicates and between replicates, a nested design was used (aquaria within temperature), thus including an additional effect in the model. Tukey's honestly significant difference test was used for post-hoc comparisons of least squared means between effect levels.

To analyse mortality, the slope of a linear regression of the relationship between mortality (proportions of dead clams) and time (days) was calculated for each replicate, following the approach of Menge et al. (2007). Mortality data were square roottransformed, thus obtaining good fits $\left(r^{2} \geq 0.762\right)$ of all relationships to the linear model. The slope of the regression could thus be taken as an appropriate measure of mortality. An analysis of variance (ANOVA), using temperature as a three-level-treatment and the slope of the regression as the response variable was used to test for effects of temperature on mortality of each species. Significant differences for between-levels were tested by the Tukey post-hocTest. Previously, the Shapiro-Wilk test and Barlett's test were used to assess normality and homogeneity of variances to meet ANOVA and ANCOVA assumptions respectively.

\section{Results}

\subsection{Growth rate}

Growth rate of $D$. obesulus was significantly dependent on shell size, with larger clams showing lower growth rates, and revealing significant differences between temperatures (Table 1, Fig. 2). Growth was fastest under NTC, followed by ENTC and slowest at LNTC. There was no significant interaction between temperature and shell size, and within aquaria variability was not significant. Post-hoc comparisons showed significant differences between NTC and LNTC and between ENTC and LNTC (Tukey test; $p<0.01$; $p=0.012$ respectively), but no differences between NTC and ENTC (Tukey test: $p=0.497$ ).

\section{Table 1}

Results of ANCOVA performed on Donax obesulus and Mesodesma donacium growth rate, with temperature as the main factor and shell size as the covariant. Significant probability values are highlighted in bold.

\begin{tabular}{lrcrr}
\hline Source of variation & DF & Sum of Squares & F-ratio & Prob $>$ F \\
\hline Donax obesulus & & & & \\
Temperature (T) & 2 & 8.865 & 9.215 & $<\mathbf{0 . 0 0 1}$ \\
Shell size (SL) & 1 & 5.627 & 11.698 & $\mathbf{0 . 0 0 1}$ \\
T $\times$ SL & 2 & 2.234 & 2.993 & 0.104 \\
Aquaria [T] & 6 & 3.751 & 4.215 & 0.061 \\
Error & 84 & 40.405 & & \\
Mesodesma donacium & & & & \\
Temperature (T) & 2 & 16.591 & 7.936 & $<\mathbf{0 . 0 0 1}$ \\
Shell size (SL) & 1 & 11.317 & 10.827 & $\mathbf{0 . 0 0 1}$ \\
T $\times$ SL & 2 & 20.425 & 9.770 & $<\mathbf{0 . 0 0 1}$ \\
Aquaria [T] & 6 & 1.799 & 0.2869 & 0.941 \\
Error & 74 & 77.346 & & \\
\hline
\end{tabular}




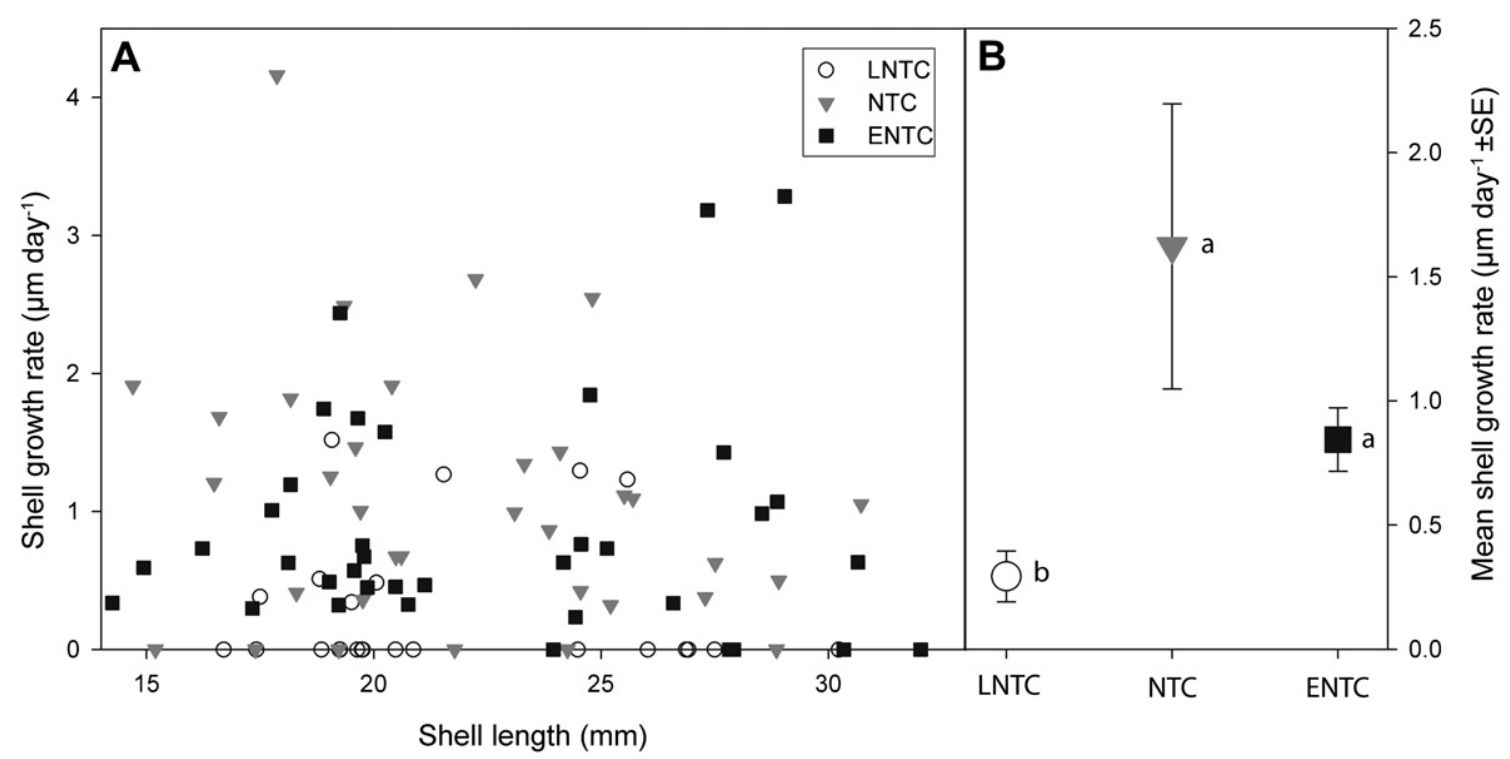

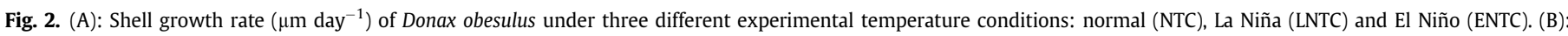

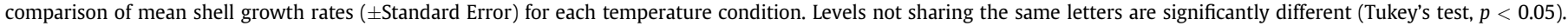

The growth rate of $M$. donacium was inversely correlated to shell size and showed significant differences between temperature regimes (Table 1, Fig. 3). A significant interaction between temperature and shell size was detected (Table 1), indicating that differences between temperatures were less clear among larger clams. Multiple a posteriori comparisons showed that growth rate of $M$. donacium differed significantly between NTC and LNTC and between NTC and ENTC (Tukey test; $p=0.021 ; p<0.01$, respectively), but did not differ between LNTC and ENTC (Tukey's HSD test: $p>0.864$ ).

\subsection{Mortality}

Mortality of $D$. obesulus revealed significant differences between experimental temperatures (Table 2), being higher and earlier at LNTC (Fig. 4). Post-hoc comparisons showed significant differences between NTC and LNTC and between ENTC and LNTC (Tukey test; $p<0.01, p=0.02$, respectively) but no significant differences between NTC and ENTC (Tukey test; $p=0.87$ ). This species showed high sensitivity to LNTC, with high mortality after 48 h of exposure and $100 \%$ mortality after three weeks. In contrast, under NTC and ENTC, a few dead specimens were observed after four days, rising slightly until day 18 . Mortality did not exceed $15 \%$ at the end of the experiment.

$M$. donacium was comparatively more resistant to changing temperatures than D. obesulus (Fig. 4). Our analysis revealed significant differences in mortality rates of $M$. donacium between experimental temperatures (Table 2). Tukey tests showed significant differences between LNTC and ENTC $(p<0.01)$ and between NTC and ENTC $(p<0.01)$. In contrast, no differences were found between LNTC and NTC (Tukey test; $p=0.91$ ) as all clams survived until the end of the experiment (Fig. 4). Under ENTC M. donacium

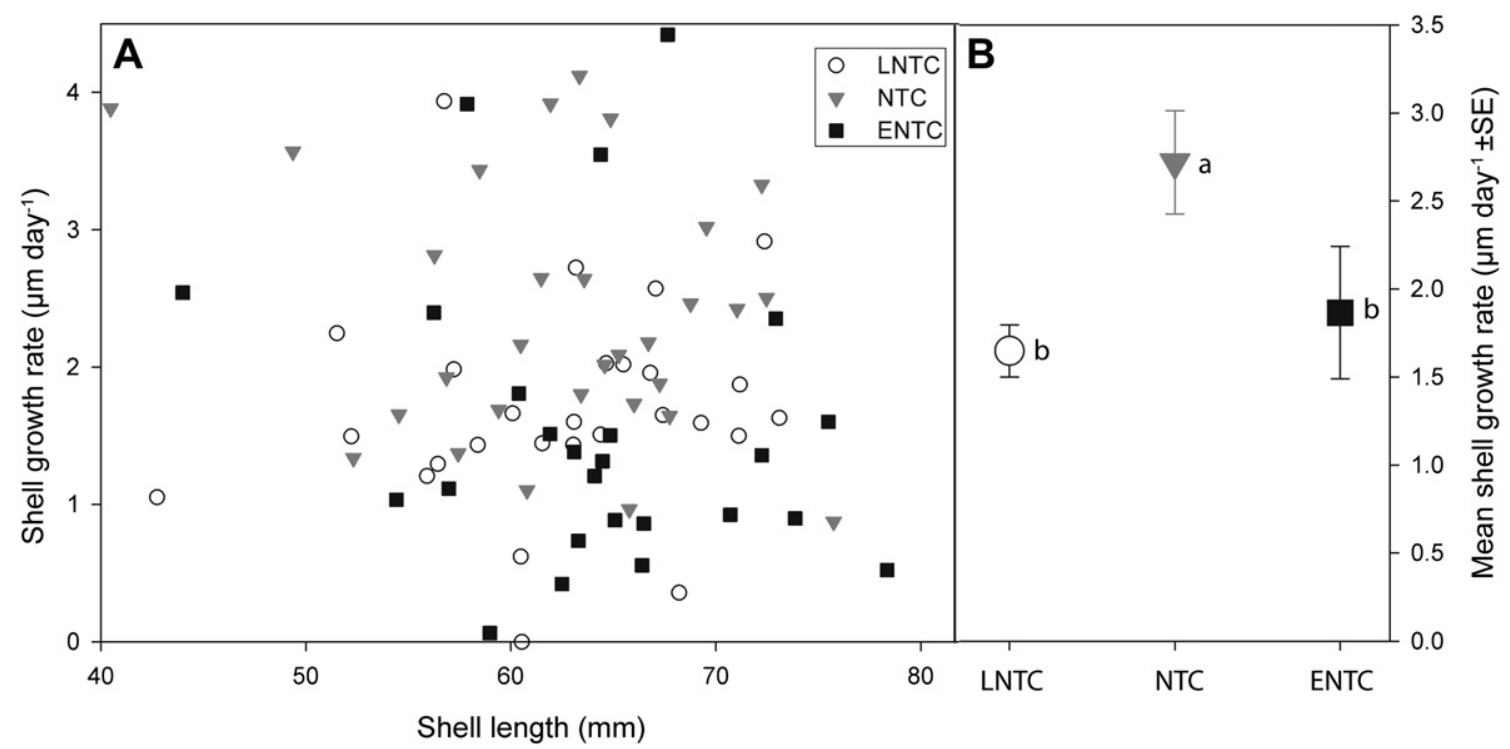

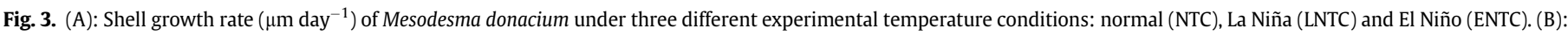

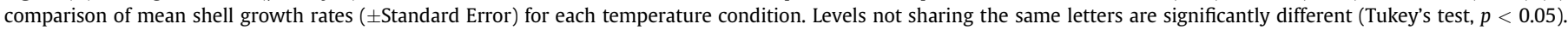


Table 2

Results of ANOVA performed to test differences of mortality of Donax obesulus and Mesodesma donacium among three temperatures. Significant probability values are highlighted in bold.

\begin{tabular}{lclcc}
\hline Source of variation & DF & Sum of squares & F-ratio & Prob $>$ F \\
\hline $\begin{array}{l}\text { Donax obesulus } \\
\text { Temperature }\end{array}$ & 2 & 0.0002 & 7.3095 & $\mathbf{0 . 0 2 4 6}$ \\
Error & 6 & 0.0001 & & \\
Mesodesma donacium & & & & \\
Temperature & 2 & 0.0014 & 42.0577 & $<\mathbf{0 . 0 0 1}$ \\
Error & 6 & 0.0001 & & \\
\hline
\end{tabular}

showed a slight increase in mortality after the tenth day with a constant trend until day 17 , thereafter increasing to $67 \%$ until the end of the experiment (Fig. 4).

As indicated by the $\mathrm{LT}_{50}$ values, $D$. obesulus responded much faster to temperature changes compared to $M$. donacium. The former species reached $\mathrm{LT}_{50}$ under LNTC after eight days, whereas $\mathrm{LT}_{50}$ of $M$. donacium under ENTC was reached at day 27 of the experiment (Fig. 4). No other level of the treatment resulted in $50 \%$ of mortality during the experimental period.

\section{Discussion}

Temperature has been considered the most significant abiotic factor controlling growth, reproduction, nutrition and other physiological processes in marine bivalves, (Laudien et al., 2001; Heilmayer et al., 2004; Miyaji et al., 2007; Riascos et al., 2009). SST in the costal HCS shows little seasonal variability and similar conditions over a broad range of latitudes. Therefore marine species are sensitive to anomalous thermal changes (Urban, 1994; Camus, 2001; Riascos et al., 2009). This study showed a high, contrasting sensitivity to short-term anomalous temperatures, with sublethal and lethal effects in both species. While $D$. obesulus was sensitive to LNTC, and tolerant to ENTC, M. donacium was sensitive to both ENTC and LNTC.

In general, the present results support the hypothesis that temperature is an important factor causing regime shifts during EN. In the period before and during EN 1982-1983 Arntz et al. (1987) followed recently-recruited cohorts of $D$. obesulus off southern Lima $\left(\sim 12^{\circ} \mathrm{S}\right)$. This species showed significantly reduced growth when SST peaked in February and March 1983, but was able to survive this strong warming event (Arntz and Fahrbach, 1991). In contrast, $M$. donacium populations exhibited mass mortality when

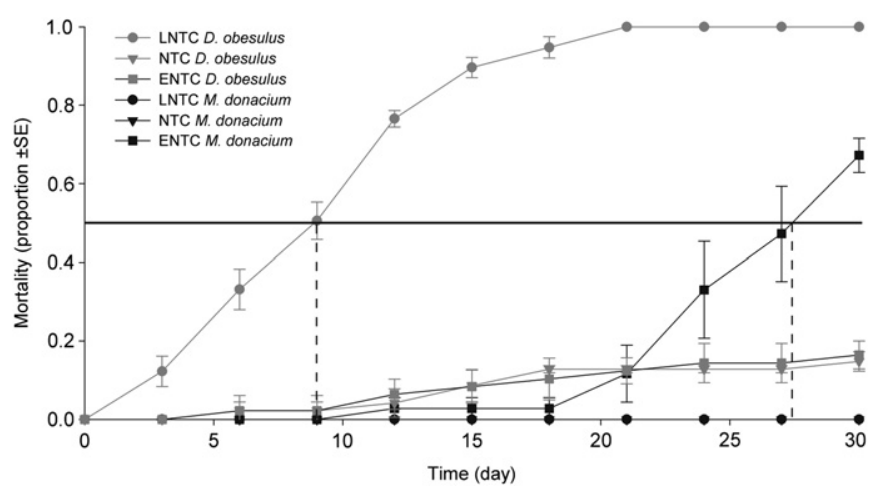

Fig. 4. Mortality of Donax obesulus and Mesodesma donacium under three different experimental temperature conditions: normal (NTC), La Niña (LNTC) and El Niño (ENTC). Vertical dashed lines indicate $\mathrm{LT}_{50}$ values for M. donacium (right) and $D$. obesulus (left).
SST peaked. Interestingly, in that studies, specimens of $M$. donacium were seen to open their shells a few days before they died, coinciding with observations made under laboratory conditions in the current study. Accordingly, the local extinction of $M$. donacium described above and the survival of $D$. obesulus after strong EN was observed repeatedly elsewhere off Peru and northern Chile (Tomicic, 1985; Arntz et al., 1987; Carbajal et al., 1995; Aburto and Stotz, 2003; Quiroz et al., 2006; Thiel et al., 2007; Riascos et al., 2009). A southward extension of the geographic distribution of $D$. obesulus has been reported following EN warming, enabling this species to temporarily reach as far south as $\sim 23^{\circ} \mathrm{S}$ (Tomicic, 1985; Carbajal et al., 1995), about $800 \mathrm{~km}$ south of its current southern distribution limit.

Despite the fact that the present results reflect responses to extreme values of a single factor and that they are spatially limited to one end of the current species distribution boundaries they may provide insights into the mechanism underlying observed changes related to EN events. However, for most EN/LN episodes, SST anomalies may be far less extreme, and species may also be affected by other factors which may either reduce or increase any potential negative temperature effects, depending on the physical characteristics of the locality. On the other hand, this study provides insights into the responses of $D$. obesulus and $M$. donacium to LN, which have been only marginally addressed in previous studies. One striking aspect of the results is that although the two clams showed opposite responses to ENTC, they both seem to be sensitive to LNTC, showing slower growth in comparison with NTC. This is probably the reason why (i) $D$. obesulus has been unable to establish viable populations within southern areas colonized during EN (Tomicic, 1985), and (ii) remnants of $M$. donacium populations are not able to rapidly recolonize northern beaches during LN (Arntz et al., 1987, 2006), as would be expected under a contrasting response pattern. Despite the fact that $D$. obesulus and $M$. donacium are sympatrically distributed along large parts of the coastal HCS, their biogeography reflects different environmental affinities, which may explain their contrasting responses to the extremes of ENSO cycle. The family Donacidae primarily inhabits warm areas, with most of the living species ( $>75 \%$ ) restricted to the tropics (Ansell, 1983). D. obesulus most likely represents a species of tropical affinity with adaptations to cooler waters. It is thus able to survive during strong EN and to expand temporarily southwards, but hampered in its ability to establish viable populations in those areas under LN conditions. In contrast, recent species of the family Mesodesmatidae generally inhabit cold and temperate waters (Marins and Levy, 1999; Beu, 2006). Therefore, the distribution and population stability of $M$. donacium seem closely linked to the interannual thermal variability associated to ENSO in the HCS (Riascos et al., 2009).

Shallow-water molluscs display significant changes in abundance associated to ENSO (e.g. Arntz and Fahrbach, 1991; Arntz et al., 2006; Thiel et al., 2007). Table 3 shows changes in abundance reported for several shallow-water molluscs distributed along the HCS (Fig. 1). Clearly, all these species show a strong nexus between their tropical/temperate origin and their changing abundance during EN (Fig. 1). Although studies exhibiting changes in abundance associated with LN appear to be almost non-existent, the present results suggest that such changes may also be dependent on biogeographical affinity. On the other hand, distributional ranges are similar for all species of tropical origin. These molluscs (Table 1) inhabit exclusively the first biogeographical unit (Thiel et al., 2007), reflecting the distributional range of $D$. obesulus (Thiel et al., 2007; Fig. 1 and Table 1). Conversely, all temperate species inhabit mainly the area of the second and third biogeographical unit (Thiel et al., 2007; Fig. 1 and Table 1), as in the case of M. donacium. 
Table 3

Effects of El Niño events on population abundance (decrease ( $\downarrow$ ); increase $(\uparrow$ ) of shallow-water molluscs of the Peruvian and Chilean coast (Arntz and Tarazona, 1990).

\begin{tabular}{|c|c|c|c|}
\hline Species (affect EN) & Origin & Distribution & References \\
\hline (1) Donax obesulus $(\uparrow)$ & tropical & $0^{\circ} 26^{\prime} \mathrm{S}$ to $23^{\circ} 05^{\prime} \mathrm{S}$ & Olsson (1961); Coan (1983) \\
\hline 2 Argopecten purpuratus $(\uparrow)$ & tropical & $0^{\circ} 55^{\prime} \mathrm{S}$ to $29^{\circ} 57^{\prime} \mathrm{S}$ & Wolff (1987); Guzmán et al. (1998b) \\
\hline (3) Thais chocolata $(\uparrow)$ & tropical & $05^{\circ} 04^{\prime} \mathrm{S}$ to $33^{\circ} 02^{\prime} \mathrm{S}$ & Keen (1971); Guzmán et al. (1998b) \\
\hline (4 Mesodesma donacium $(\downarrow)$ & subantarctic & $16^{\circ} 36^{\prime} S$ to $42^{\circ} 23^{\prime} S$ & von Ihering (1907); Tarifeño (1980) \\
\hline (5 Semimytilus algosus $(\downarrow)$ & temperate & $03^{\circ} 34^{\prime} \mathrm{S}$ to $36^{\circ} 54^{\prime} \mathrm{S}$ & Olsson (1961); Caro and Castilla (2004) \\
\hline (6 Aulacomya ater $(\downarrow)$ & temperate & $12^{\circ} 03^{\prime} \mathrm{S}$ to $52^{\circ} 46^{\prime} \mathrm{S}$ & Jaramillo and Navarro (1995); Guzmán et al. (1998b) \\
\hline
\end{tabular}

The responses to changing temperature regimes depicted here may also operate at larger temporal scales. Inter-decadal shifts in the biological regimes of pelagic ecosystems corresponding to shifts in fundamental physical properties of the HCS are now being recognized (e.g. Bakun and Broad, 2003; Chavez et al., 2003; Montecinos et al., 2003; Ayón and Swartzman, 2008). Although no attempt has been made to evaluate potential effects in coastal populations of the HCS, a strong effect seems feasible (Southward et al., 1995). Moreover, the hypothesized increase in the frequency of ENSO under a scenario of ongoing global warming (Timmermann et al., 1999) may significantly affect current distribution and abundance patterns of coastal species in the HCS.

Even though our results support the hypothesis of a strong link between temperature tolerance, anomalous temperature and distribution shifts of $D$. obesulus and $M$. donacium, we cannot expect those shifts to be explained solely in terms of this relationship. There are several further biotic and abiotic processes that have to be taken into account for a proper understanding of the biological responses of these species to ENSO. A whole array of abiotic factors is modified during ENSO, notably salinity, wave action, sediment load, upwelling strength and hence nutrient and food availability, which act simultaneously to produce an integrated effect on these species (e.g. Arntz et al., 2006) that may be difficult to address in experimental studies.

Interspecific interactions play an important role in defining population processes and community structure in sandy beach ecosystems (see review by Defeo and McLachlan, 2005). These interactions may be significantly modified under strong environmental stress and may modulate the responses of species to the extremes of ENSO. These interactions may be implicated in the poor ability of $M$. donacium to recover its former abundance and distribution and in the inability of $D$. obesulus to thrive at southern beaches in the wake of EN events. However, it is not clear whether competition occurs between these clams: After the mass mortality of $M$. donacium in Peru during EN 1982-1983, D. obesulus and the mole crab Emerita analoga never reached the density formerly attained by $M$. donacium; instead, an impoverished community consisting mainly of small opportunistic polychaetes became established, leading Arntz et al. (1987) to suggest that no competition exists between these commonly dominant species. On the other hand, the parasitic association between $M$. donacium and the spionid Polydora bioccipitalis may also play a role in the process of recovery of abundance and distribution range after strong warming events (Riascos et al., 2008).

\section{Acknowledgements}

This study represents part of the first author's Ph.D. thesis and was financially supported by the University of Bremen, the German Academic Exchange Service (DAAD) and the International Bureau of the Federal Ministry of Education and Research. We are grateful to Marcelo Oliva and to Leonel González of the University of Antofagasta for their essential help. We are very grateful for the comments of two anonymous referees that improved our manuscript considerably. The work was conducted as part of the EU-funded
FP6-INCO-STREP project, Climate Variability and El Niño-Southern Oscillation: Implications for Natural Coastal Resources and Management (CENSOR-CT-2004-511071) and is CENSOR publication $\mathrm{N}^{\circ} 385$.

\section{References}

Aburto, J., Stotz, W., 2003. Una experiencia de co-manejo de bivalvos en el marco de una nueva herramienta de administración pesquera en Chile: las áreas de manejo. Policy Matters 12, 200-204.

Ansell, A.D. 1983. The biology of the genus Donax. In: McLachlan, A., Erasmus, T. Junk, W.E. (Eds.), Developments in Hydrobiology Vol. 19: Sandy Beaches as Ecosystems, vol. 19. Dr. W. Junk, The Hague, Netherlands, pp. 607-635.

Arntz, W., Tarazona, J., 1990. Effects of El Niño 1982-1983 on Benthos, Fish and Fisheries off the South American Pacific Coast. In: Glynn, P.W. (Ed.), Global Ecological Consequences of the 1982-1983 El Niño-Southern Oscillation. Elsevier Oceanography Series, pp. 323-360.

Arntz, W.E. Brey, T. Tarazona, J., Robles, A., 1987. Changes in the structure of a shallow sandy-beach community in Peru during an El Niño event. South African Journal of Marine Science 5, 645-658.

Arntz, W.E., Fahrbach, E., 1991. El Niño-Klimaexperiment der Natur: Physikalische Ursachen und biologische Folgen. Birkhäuser, Basel, 264 pp.

Arntz, W.E., Gallardo, V.A., Gutiérrez, D., Isla, E., Levin, L.A., Mendo, J., Neira, C., Rowe, G.T., Tarazona, J., Wolff, M., 2006. El Niño and similar perturbation effects on the benthos of the Humboldt, California, and Benguela Current upwelling ecosystems. Advances in Geosciences 6, 243-265.

Arntz, W.E., Valdivia, E., Zeballos, J., 1988. Impact of El Niño 1982-83 on the commercially exploited invertebrates (mariscos) of the Peruvian shore. Meeresforschung 32, 3-22.

Ayón, P., Swartzman, G., 2008. Changes in the long-term distribution of zooplankton in the Humboldt Current Ecosystem off Peru, 1961-2005, and its relationship to regime shifts and environmental factors. Fisheries Oceanography $17,421-431$.

Bakun, A., Broad, K., 2003. Environmental 'loopholes' and fish population dynamics: comparative pattern recognition with focus on El Niño effects in the Pacific. Fisheries Oceanography 12, 458-473.

Beu, A.G., 2006. Marine Mollusca of oxygen isotope stages of the last 2 million years in New Zealand. Part 2. Biostratigraphically useful and new Pliocene to recent bivalves. Journal of the Royal Society of New Zealand 36, 151-338.

Camus, P.A., 2001. Biogeografía marina de Chile continental. Revista Chilena de Historia Natural 74, 587-617.

Carbajal, W., Carrasco, F.D., Curo, P., Zamora, J., 1995. Cambios en la estructura comunitaria de la macroinfauna de playas arenosas, después del fenómeno El Niño 1986-1987, en Lambayeque, Perú. Gayana Oceanologia 3, 29-40.

Caro, A.U., Castilla, J.C., 2004. Predator-inducible defences and local intrapopulation variability of the intertidal mussel Semimytilus algosus in Central Chile. Marine Ecology Progress Series 276, 115-123.

Carstensen, D., 2010. Environmentally induced responses of Donax obesulus and Mesodesma donacium (Bivalvia) inhabiting the Humboldt Current System, Ph. D. thesis. University Bremen. $160 \mathrm{p}$.

Carstensen, D., Laudien, J., Leese, F., Arntz, W.E., Held, C., 2009. Genetic variability, shell and sperm morphology suggest that the surf clams Donax marincovich and D. obesulus are one species. Journal of Molluscan Studies 75, 381-390.

Castilla, J.C., Camus, P.A., 1992. The Humboldt-El Niño scenario: coastal benthic resources and anthropogenic influences, with particular references to the 1982/ 83 ENSO. South African Journal of Marine Science 12, 703-712.

Chavez, F.P., Ryan, J., Lluch-Cota, S.E., Ñiquen, C.M., 2003. From anchovies to sardines and back: multidecadal change in the Pacific Ocean. Science 299, 217-221.

Coan, E., 1983. The Eastern Pacific Donacidae. The Veliger 25, 273-298.

Defeo, O., de Alava, A., 1995. Effects of human activities on long-term trends in sandy beach populations: the wedge clam Donax hanleyanus in Uruguay. Marine Ecology Progress Series 123, 73-82.

Defeo, O., McLachlan, A., 2005. Patterns, processes and regulatory mechanisms in sandy beach macrofauna: a multi-scale analysis. Marine Ecology Progress Series 295, 1-20.

Díaz, A., Ortlieb, L., 1993. El fenómeno ‘El Niño’ y los moluscos de la costa peruana. Bulletin de I'Institut Francais d'Études Andines 22, 159-177.

Dugan, J.E., Jaramillo, E., Hubbard, D.M., Contreras, H., Duarte, C., 2004. Competitive interactions in macroinfaunal animals of exposed sandy beaches. Oecologia 139, 630-640. 
Guzmán, J.M., Viana, M.T., 1998a. Growth of abalone Haliotis fulgens fed diets with and without fish meal, compared to a commercial diet. Aquaculture 165, 321-331.

Guzmán, N., Saá, S., Ortlieb, L., 1998b. Catálogo descriptivo de los moluscos litorales (Gastropoda y Pelecypoda) de la zona de Antofagasta $23^{\circ} \mathrm{S}$ (Chile). Estudios Oceanológicos 17, 17-86.

Heilmayer, O., Brey, T., Pörtner, H.O., 2004. Growth efficiency and temperature in scallops: a comparative analysis of species adapted to different temperatures. Functional Ecology 18, 641-647.

Herrmann, M., Carstensen, D., Fischer, S., Laudien, J., Penchaszádeh, P.E., Arntz, W.E. 2009. Population structure, growth and production of the wedge clam Donax hanleyanus (Bivalvia: Donacidae) from northern Argentinean beaches. Journa of Shellfish Research 28, 1-16.

Jaramillo, R., Navarro, J., 1995. Reproductive cycle of the Chilean ribbed mussel, Aulacomya ater (Molina, 1782). Journal of Shellfish Research 14, 165-171.

Keen, A.M., 1971. Sea Shells of Tropical West America, 2 ed. Standford University Press, Standford, California, $1064 \mathrm{pp}$.

Laudien, J., Brey, T., Arntz, W.E., 2001. Reproduction and recruitment patterns of the surf clam Donax serra (Bivalvia, Donacidae) on two Namibian sandy beaches. South African Journal of Marine Science 23, 53-60.

Laudien, J., Rojo, M.E., Oliva, M.E., Arntz, W.E., Thatje, S., 2007. Sublittoral soft bottom communities and diversity of Mejillones bay in northern Chile (Humboldt current upwelling system). Helgoland Marine Research 61, 103-116.

Marins, L.F., Levy, J.A., 1999. High genetic distance between marine bivalves of the genus Mesodesma inhabiting the Atlantic and Pacific coasts of South America. Comparative Biochemistry and Physiology 124, 313-319.

Menge, B.A., Daley, B.A., Sanford, E., Dahlhoff, E.P., Lubchenco, J., 2007. Musse zonation in New Zealand: an integrative eco-physiological approach. Marine Ecology Progress Series 345, 129-140.

Miyaji, T, Tanabe, K, Schöne, B.R, 2007. Environmental controls on daily shell growth of Phacosoma japonicum (Bivalvia: Veneridae) from Japan. Marine Ecology Progress Series 336, 141-150.

Montecinos, A., Purca, S., Pizarro, O., 2003. Interannual-to-interdecadal sea surface temperature variability along the western coast of South America. Geophysical Research Letters 30, 1570.

Olsson, A.A., 1961. Mollusks of the Tropical Eastern Pacific, Panamic Pacific Pelecypoda. Paleontological Research Institute, Ithaca, 574 pp.

Pörtner, H.O., Knust, R., 2007. Climate change affects marine fishes through the oxygen limitation of thermal tolerance. Science 315, 95-97.

Pörtner, H.O., Storch, D., Heilmayer, O., 2005. Constraints and trade-offs in climatedependent adaptation: energy budgets and growth in a latitudinal cline. Sciencias Marinas 69, 271-285.

Quiroz., M., Tejada, A., Gonzales, A., Castillo, R., 2006.esEstrategia para reforzar e repoblamiento natural del recurso macha (Mesodesma donacium, Lamarck 1818) en el litoral de la provincia de Islay, región Arequipa-Perú. Informe Instituto del Mar del Perú CCM013, p. 33-4.

Riascos, J.M., 2006. Effects of el Niño-southern Oscillation on the population dynamics of the tropical bivalve Donax dentifer from Málaga bay, Colombian Pacific. Marine Biology 148, 1283-1293.

Riascos, J.M., 2008. Thriving and declining: population dynamics of the macha (Mesodesma donacium, Bivalvia, Mesodesmatidae) along a latitudinal gradient of the Humboldt Current Upwelling System, Ph.D. thesis. University Bremen. 124 p.

Riascos, J.M., Carstensen, D., Laudien, J., Arntz, W., Oliva, M.E., Güntner, A. Heilmayer, O., 2009. Thriving and declining: temperature and salinity shaping life-history and population stability of Mesodesma donacium in the Humbold Upwelling System. Marine Ecology Progress Series 385, 151-163.
Riascos, J.M., Guzmán, N., Laudien, J., Heilmayer, O., Oliva, M.E., 2007. Suitability of three stains to mark shells of Concholepas concholepas (Gastropoda) and Mesodesma donacium (Bivalvia). Journal of Shellfish Research 26, 1-7.

Riascos, J.M., Heilmayer, O., Oliva, M.E., Laudien, J., Arntz, W.E., 2008. Infestation of the surf clam Mesodesma donacium by the spinoid polychaete Polydora biocipitalis. Journal of Sea Research 59, 217-227.

Sagarin, R.D., Gaines, S.D., Gaylord, B., 2006. Moving beyond assumptions to understand abundance distributions across the ranges of species. Trends in Ecology and Evolution 21, 524-530.

Soto, R., 1985. Efectos del fenómeno El Niño 1982-83 en ecosistemas de la I Región. Investigación Pesquera 32, 199-206.

Southward, A.J., Hawkins, S.J., Burrows, M.T., 1995. Seventy years observations of changes in distribution and abundance of zooplankton and intertidal organisms in the western English Channel in relation to rising sea temperature. Journal of Thermal Biology 20, 127-155.

Tarazona, J., Arntz, W.E., Canahuire, E., Ayala, Z., Robles, A., 1985. Modificaciones producidas durante 'El Niño' en la infauna bentónica de áreas someras del ecosistema de afloramiento peruano. In: Arntz, W.E., Landa, A., Tarazona, J. (Eds.), 'El Niño', su impacto en la fauna marina. Boln. Inst. Mar. Perú, Callao, pp. 55-63. Spec. Issue.

Tarazona, J., Paredes, C., Igreda, M., 1986. Estructura del macrobentos en las playas arenosas de la zona de Lima, Perú, 74. Revista de Ciencias U.N.M.S.M. 103-116.

Tarifeño, E., 1980. Studies on the biology of the surf-clam Mesodesma donacium (Lamarck, 1818) (Bivalvia: Mesodesmatidae) from Chilean sandy beaches, Ph.D. thesis. University of California, Los Angeles, 203 p.

Thatje, S., Heilmayer, O., Laudien, J., 2008. Climate variability and El Niño Southern Oscillation: implications for natural coastal resources and management. Helgoland Marine Research 62, 5-14.

Thiel, M., Macaya, E.C., Acuña, E., Arntz, W., Bastias, H., Brokordt, K., Camus, P.A., Castilla, J.C., Castro, L.R., Cortés, M., Dumont, C.P., Escribano, R., Fernández, M., Gajardo, J.A., Gaymer, C.F., Gómez, I., González, A.E., González, H.E., Haye, P.A., Illanes, J.E., Iriarte, J.L., Lancellotti, D.A., LunaJorquera, G., Luxordo, C., Manríquez, P.H., Marin, V., Muñoz, P., Navarrete, S. A., Pérez, E., Poulin, E., Sellanes, J., Sepúlveda, H.H., Stotz, W., Tala, F., Thomas, A., Vargas, C.A., Vásquez, J.A., Vega, J.M.A., 2007. The Humboldt current system of northern and central Chile, oceanographic processes, ecological interactions and socioeconomic feedback. Oceanography and Marine Biology 45, 195-345.

Timmermann, A., Oberhuber, J., Bacher, A., Esch, M., Latif, M., Roeckner, E., 1999. Increased El Niño frequency in a climate model forced by future greenhouse warming. Nature 398, 694-697.

Tomicic, J.J., 1985. El Niño 1982-83 effects on the littoral communities of the Peninsula de Mejillones. Investigacion Pesquera 32, 209-213.

Urban, H.J., 1994. Upper temperature tolerance of ten bivalve species off Peru and Chile related to El Niño. Marine Ecology Progress Series 107, 139-145.

von Ihering, H., 1907. Les mollusques fossiles du tertiaire et du cretacé supérieur de l'Argentine. Anales del Museo Nacional de Buenos Aires ser. II, 611 pp.

Wang, H.J., Zhang, R.H., Cole, J., Chavez, F., 1999. El Niño and the related phenomenon Southern Oscillation (ENSO): the largest signal in interannual climate variation. Proceedings of the Academy of Natural Sciences 96, 11071-11072.

Wang, T., Overgaard, J., 2007. The heartbreak of adapting to global warming. Science 315, 49-50.

Wolff, M., 1987. Population dynamics of the Peruvian scallop Argopecten purpuratus during the El Niño phenomenon of 1983. Canadian Journal of Fisheries and Aquatic Sciences 44, 1684-1691. 